\title{
Predicted range shifts of dragonflies over a wide elevation gradient in the southern hemisphere
}

\author{
John P. Simaika ${ }^{1,2}$ and Michael J. Samways ${ }^{1,3}$ \\ ${ }^{1}$ Department of Conservation Ecology and Entomology and Centre for Invasion Biology, University of Stellenbosch, Private Bag X1, \\ Matieland 7602 South Africa
}

\begin{abstract}
Human-induced climate change is among the greatest threats to biodiversity, especially when coupled with habitat destruction. For an already water-stressed country like South Africa, changes in temperature and precipitation regimes, coupled with increasing water demands, are likely to lead to losses in biodiversity. Dragonflies are a well-studied surrogate taxon for aspects of freshwater biodiversity. We created species distribution models for 14 dragonfly species, and predicted the changes in species richness, extent of occurrence, and habitat suitability for the years 2050 and 2080 in South Africa, a poorly studied area for range-change predictions for insects. Model predictions for 2 different emissions scenarios suggest that at least 2 species will be lost from the area by 2050, and 3 by 2080. All are widespread Afrotropical species, but with narrow elevation ranges in South Africa. Only 1 species is predicted to benefit greatly from climate change. The remaining species are predicted to persist with reduced extents of occurrences at higher elevations. Most species we studied (12 of 14) thrive in artificial environments. Therefore, to a certain extent, loss in connectivity is unlikely to play a role for these species. However, the 2 stream specialists that occur in the area are particularly vulnerable because of loss of habitat. Species that currently occur farther north in southern Africa and South Africa also are likely to move southward in the future. Thus, species richness may not necessarily decrease, but replacement of species within communities will be significant.
\end{abstract}

Key words: climate change, freshwater, aquatic biodiversity, dragonfly, South Africa

Anthropogenic climatic change, especially when synergistic with habitat loss, has emerged as among the greatest threats to global biodiversity (e.g., Brooke 2008, Bellard et al. 2012). Climate changes all the time, but the current and future rate and magnitude of change is of concern. Global patterns of temperature and precipitation are predicted to change greatly, altering the distribution of rivers and wetlands (Dawson et al. 2003, Middleton and Kleinebecker 2012). In addition, climate change coupled with habitat loss and reduced connectivity, invasion by alien organisms, water abstraction, and pollution are likely to prevent freshwater species from adapting at a rate fast enough to cope with local and regional changes (Dudgeon et al. 2006; but see Stuart et al. 2014 on rapid evolutionary change on observable time scales).

The future climate of South Africa, already a waterscarce country, is predicted to increase in temperature and decrease in precipitation (Driver et al. 2005). Rivers are the primary source of water (85\%) for agricultural, domestic, and industrial use. Dams provide the remainder (15\%), and the water stored behind dams accounts for $67 \%$ of the total annual runoff in all rivers. In a study assessing the status of major river ecosystems in South Africa, Nel et al. (2007) found that $23 \%$ of the length of the country's main rivers has been irreversibly transformed. Coupled with ever increasing water withdrawals and effluent discharge, aquatic diversity is bound to decline further in other systems, causing associated losses in ecosystem services (Driver et al. 2005, MA 2005).

Monitoring the effect on biodiversity of such large-scale and ubiquitous changes requires careful selection of bioindicators. Adult dragonflies make excellent surrogates for the assessment of aquatic systems (Schindler et al. 2003, Darwall et al. 2011). They are used as indicators of ecological health (Trevino 1997), ecological integrity (Simaika and Samways 2009a), and environmental change, including habitat recovery (Samways et al. 2011) and climate change (Hassall and Thompson 2008, Bush et al. 2013). Distributional changes in dragonflies caused by anthropogenic climate change have been studied in Europe. Ott (2011) demonstrated the expansion of Mediterranean species into northern Europe. Compared with baseline data from 1988,

E-mail addresses: ${ }^{2}$ simaikaj@sun.ac.za; ${ }^{3}$ samways@sun.ac.za 
13 species of Mediterranean origin have expanded their range, and 2 more were assessed as having a greater tendency to migrate or invade. Species from the dragonfly genera Aeshna (2), Anax (3), Boyeria (1), Crocothemis (1), Erythromma (2), Gomphus (1), Oxygastra (1), and Sympetrum (2) were well represented on this list of species, but some damselfly species from the genera Coenagrion and Lestes also are expanding their ranges. Most of the expansions are into northern Germany, the UK, Finland, Denmark, Sweden, and Poland. Ott (2011) also showed that the ranges of several Eurosiberian species Coenagrion hastulatum, Aeshna juncea, Somatochlora arctica, and Leucorrhinia dubia are contracting and that some local or regional populations are extinct.

The dragonfly fauna of South Africa is composed of specialist and generalist species that show lower levels of endemism than many other insect taxa and little dependence on plant composition (Grant and Samways 2007). The mountainous southwestern area of the country is a center of endemism for dragonflies, whereas the speciesrich northeastern area is dominated by Afrotropical species (Simaika and Samways 2009b). This distribution pattern reflects patterns found by Wishart and Day (2002) for other freshwater invertebrates and vertebrates. Small reservoirs, such as pools or farm reservoirs, are encountered frequently on the landscape and are important reserves for dragonflies (Samways 1989). Such reservoirs increase the area of occupancy of local, albeit generalist species, and from a dragonfly's point of view, increase the connectivity of the landscape. Furthermore, in KwaZulu-Natal, the dragonfly assemblages are highly elevation tolerant and vagile, traits apparently honed by past El Niño Southern Oscillation (ENSO) events (Samways and Niba 2011).

Species distribution models (SDMs) are frequently used to model current and future distributions of species (Franklin 2010, Simaika et al. 2013, De Marco et al. 2015). These models seek to predict habitat suitability at unsampled locations by combining the data on the observed location of a species (presence) with environmental data. The applications of such models are varied. Investigators have used SDMs to guide field surveys (e.g., Bourg et al. 2005), predict species invasions (e.g., Ficetola et al. 2007), plan for conservation (e.g., Elith and Leathwick 2009), and project potential impacts of climate change (e.g., Thomas et al. 2004). Our objective was to understand how the distributions of a subset of South African dragonflies will be affected by global climate change in the medium to long term.

For South African Odonata, we expect the Afrotropical, largely habitat-tolerant species to increase their extent of occurrence because additional suitable climate spaces will become available for Afrotropical species as temperatures undergo expected increases and precipitation undergoes expected decreases. Furthermore, we predict that endemic habitat specialists (usually stream species) will have dimin- ished extents of occurrence as they move to higher elevations where less habitat is available in their climate envelope. In addition, adverse changes to habitats that arise from climate change (increased woody vegetation growth, sedimentation, flood events) are expected to have further adverse effects on larval habitats. We expect species richness to remain similar to current conditions as specialist species are replaced by an increasingly generalist fauna. Last, we expect habitat suitability (i.e., available climate envelopes) to decrease for the dragonfly fauna overall. The goal of our study was to investigate the effect of climate change on: 1) species geographic spread and elevation range of endemic habitat specialist species in comparison to Afrotropical generalist species, 2) species richness patterns, and 3) habitat suitability (i.e., climatic suitability).

\section{METHODS}

\section{Study area and sampling records}

Our study area was in the province of KwaZulu-Natal (South Africa) and extended from the coast to the Drakensberg mountains. At sea level, a subtropical to tropical climate prevails, whereas higher elevations are temperate to alpine. Elevation range is 0 to $3408 \mathrm{~m}$ asl. The location is ideal for such an elevation study because the gradient runs from east to west. Thus, the gradient does not include changes in latitude. We extracted collection and observation records for our study from a larger, national data set of dragonfly species (Simaika and Samways 2009b). We obtained additional data from a study on the elevation tolerance of dragonflies in the same area (Samways and Niba 2010). As a minimum selection criterion, we used species with $\geq 20$ unique sampling locations (i.e., 1 sampling location/grid cell), resulting in 14 species representing a total of 259 records and 77 unique sampling locations (Fig. 1). A list of the species and a faunal description is given in Table 1.

\section{Environmental variables}

We obtained 30 -arc-second $\left(\sim 1-\mathrm{km}^{2}\right.$ cell size), climate raster data sets of bioclimatic variables, which are biologically relevant variables calculated from elevation, temperature, and precipitation (Hijmans et al. 2005a). In addition to current climate data (1950-2000 average), we obtained coupled global climate data from the IPCC $4^{\text {th }}$ Assessment (IPCC 2007) of future climate projections for the years 2050 and 2080. The future climate projections came from 3 global climate models: the Canadian Centre for Global Climate Modeling and Analysis (CCCma), the Commonwealth Scientific and Industrial Research Organization (CSIRO), and Hadley Centre Coupled Model V3 (HadCM3). Each model was tested under 2 emissions scenarios (A2 and B2). The A2 scenario assumes that population growth does not slow down and the population reaches 15 billion by 2100 , and is associated with an increase in emissions. The B2 scenario assumes slower population growth, reach- 


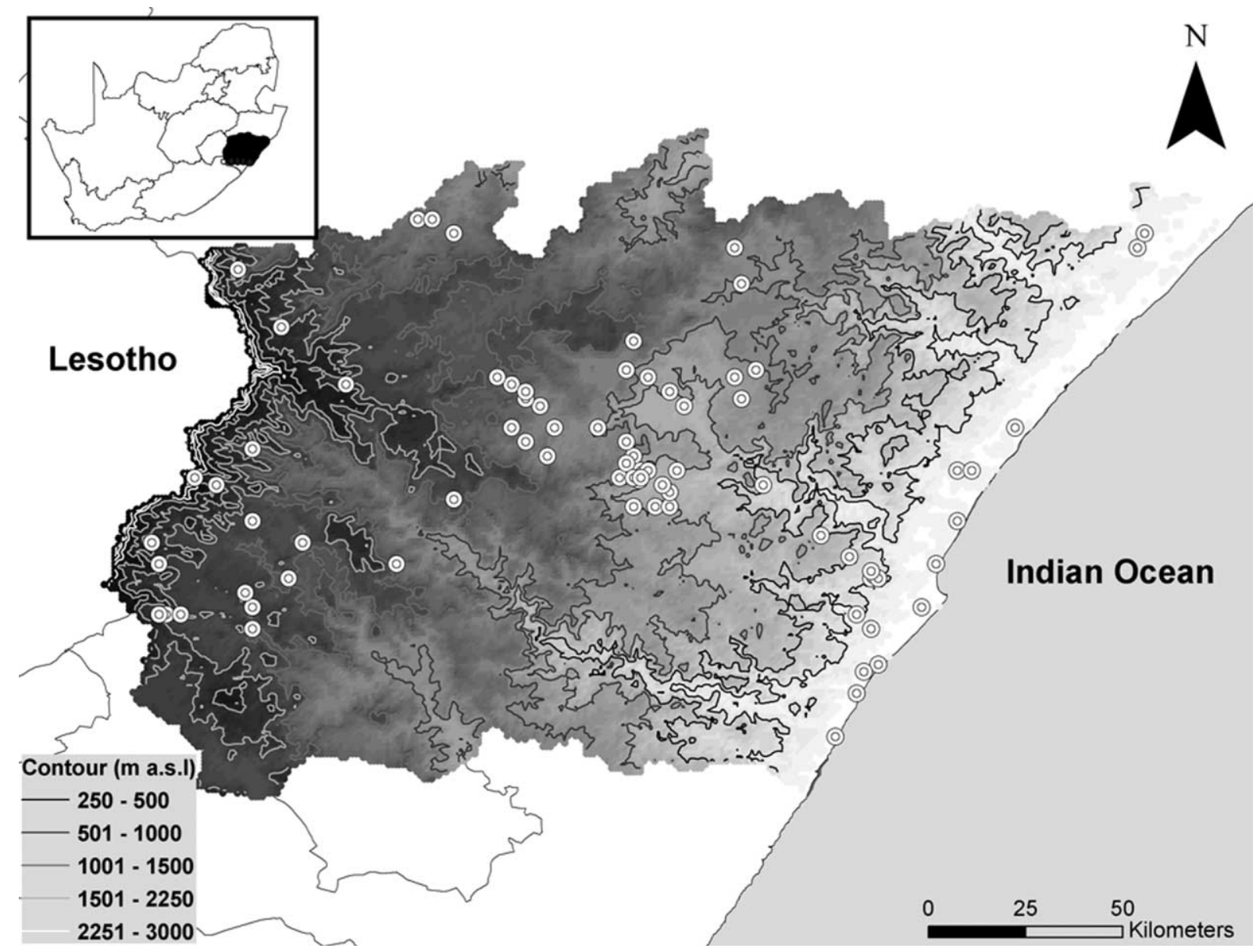

Figure 1. The study area, in KwaZulu-Natal, South Africa. White double circles are sampling locations. Shaded areas indicate increasing elevation from low (light gray) to high (dark gray).

ing 10.4 billion by 2100 , and assumes that precautionary environmental practices are implemented (IPCC 2007). In addition to the climate rasters, we used a river catchment areas map, at the Quaternary scale (Midgley et al. 1994). Bioclimatic variables for the future scenarios were calculated using DIVA-GIS (version 7.2; Hijmans et al. 2005b).

\section{Species habitat modeling}

For this study, we used the species distribution modeling (SDM) software package MaxEnt (version 3.3.3a; Phillips et al. 2006, Phillips and Dudík 2008). MaxEnt has been used extensively for constructing SDMs, including in studies on dragonflies (e.g., Shah et al. 2012, Wellenreuther et al. 2012, De Marco et al. 2015). MaxEnt was run using default parameters. To check for multicollinearity, we used a Spearman rank-correlation analysis on the normalized environmental variables. The use of multicollinear variables may cause overfitting of models, and makes the interpretation of variable importance impossible (Phillips et al. 2006). We used jackknife tests to re- move variables that did not significantly contribute to model predictions. In our study, a minimum of 20 unique locations ( 1 presence per grid cell) was required for species to be admitted for modeling. For each species, we replicated 100 runs with $75 \%$ of a species' records randomly selected for model training and cross-validation, and we set aside $25 \%$ of the data for model testing and independent validation. The importance of environmental variables will differ among species, and therefore, we built different models for each species. We compared and validated model results using the area under the receiver operating characteristic curve (AUC). The AUC measures the ability of models to discriminate presence from absence records. An AUC value of 0.5 in the model would be equivalent to a random guess, whereas a value of 1.0 would indicate that the model can perfectly distinguish between presence and absence of a species (Elith et al. 2006). Suggestions on what minimum AUC values have a useful amount of discrimination vary from AUC $>0.7$ (Pearce and Ferrier 2000) and the frequently quoted AUC $>0.75$ (Elith et al. 2006) to AUC > 0.85 (Newbold 2010). To take uncertainty into consideration, we selected spe- 
Table 1. Descriptions of species geographic ranges, habitat preferences, and flight season (season). SA = South Africa.

\begin{tabular}{|c|c|c|c|}
\hline Species & Range & Habitat & Season \\
\hline Africallagma glaucum & Throughout SA to tropical Africa & Marshy areas with emergent vegetation & All year \\
\hline Brachythemis leucosticta & $\begin{array}{l}\text { Northeastern SA to eastern } \\
\text { and western Africa }\end{array}$ & Pools, dams, sluggish rivers & November-May \\
\hline Chlorolestes fasciatus & Endemic to SA & Streams and rivers & December-May \\
\hline Chlorolestes tessellatus & Endemic to SA & Forested streams and rivers & December-May \\
\hline Hemistigma albipunctum & $\begin{array}{l}\text { KwaZulu-Natal coast } \\
\text { to central Africa }\end{array}$ & Pools with emergent vegetation & November-May \\
\hline Lestes virgatus & $\begin{array}{l}\text { SA to northern and } \\
\text { western Africa }\end{array}$ & Pools with emergent vegetation & November-May \\
\hline Nesciothemis farinosa & $\begin{array}{l}\text { SA to Egypt and } \\
\text { southern Arabia }\end{array}$ & Pools, pans, sluggish rivers & October-May \\
\hline Palpopleura portia & $\begin{array}{l}\text { Northeastern SA to eastern } \\
\text { and western Africa }\end{array}$ & $\begin{array}{l}\text { Ponds, pools, pans, swamps, marshes, } \\
\text { sluggish rivers }\end{array}$ & October-May \\
\hline Pseudagrion kersteni & $\begin{array}{l}\text { Throughout SA to tropical Africa, } \\
\text { rare at coast }\end{array}$ & Vegetated banks of streams and rivers & All year \\
\hline Pseudagrion massaicum & $\begin{array}{c}\text { Throughout SA to tropical Africa, } \\
\text { north to Ethiopia and Uganda }\end{array}$ & Ponds, pools, sluggish rivers & October-May \\
\hline Pseudagrion spernatum & Mountains of SA, $>800 \mathrm{~m}$ asl & Fast-flowing montane streams and rivers & October-May \\
\hline Trithemis arteriosa & $\begin{array}{l}\text { Throughout SA to tropical } \\
\text { Africa and Asia }\end{array}$ & Pools, dams, still reaches of rivers & All year \\
\hline Trithemis dorsalis & $\begin{array}{l}\text { Throughout SA to tropical } \\
\text { Africa and Asia }\end{array}$ & Lakes, dams, still reaches of rivers & November-May \\
\hline Trithemis furva & $\begin{array}{l}<700 \mathrm{~m} \text { asl, throughout SA } \\
\text { to Ethiopia and western Africa }\end{array}$ & Rocky, shallow rivers & All year \\
\hline
\end{tabular}

cies models that had an AUC value $>0.7$ after subtraction of the lower $95 \%$ confidence interval of the average model species AUCs, calculated from the model test samples and related standard deviation. Selected model AUCs ranged from 0.76 to 0.96. After subtraction of the lower 95\% confidence interval, the lower AUC values ranged from 0.70 to 0.94 .

\section{Spatial analysis}

To assess changes in species richness and geographic range, we converted the species models meeting the AUC criteria into presence-absence (binary) data sets. The binary maps were created using the minimum logistic presence threshold; i.e., we considered suitable all sites that were at least as suitable as those where a species presence was recorded in the training set. This threshold is considered conservative because it identifies the minimum predicted area possible while maintaining 0 omission error in the training data set. Species were considered present in a grid cell only above the training presence threshold, averaged over all 100 runs for each species. In addition to this criterion, $\geq 2$ models had to agree on the presence of a species in a grid cell to be considered a presence. Species geographic range was defined as the sum of the presence scores (i.e., number of grid cells) across the study area, and species richness as the number of species considered present in each grid cell. Species minimum and maximum elevations were calculated as the average of 10 grid cells of lowest or highest value, respectively. The potential change in species distribution under climate change was computed by differentially weighting grid cells of current and future suitable (current $=1$, future $=4$ ) and nonsuitable habitat (current $=0$, future $=2$ ) for each prediction and then adding current predictions to future predictions. This method allowed us to classify areas as unsuitable (current and future), stable (suitable currently and in the future), increasingly suitable in the future, and decreasingly suitable in the future (unsuitable $=2$, stable $=5$, increasing $=4$, decreasing $=3$ ) under future climate scenarios. All spatial work was carried out using ArcGIS (version 9.2; Environmental Systems Research Institute, Redlands, California).

\section{RESULTS \\ Models and variables}

All variables used in model building were correlated $(r>$ $0.8, p<0.01)$, and thus, interpretation of variable importance to models was not possible. Eight models were created for species under different climate scenarios. The most com- 
monly used variables were catchment area (all models), minimum temperature of the coldest month (4 models), mean temperature of the driest month (4 models), and precipitation of the warmest quarter (4 models) (Table 2 ).

\section{Species richness}

In the current situation, using predicted distributions, species richness is and will be highest in the midlands (13 species; Fig. 2). Richness at the coast is lower (8 species), and richness is lowest in the highlands (5-6 species). Under the more severe emissions scenario (A2) for the year 2050, few species (1-2) are predicted to occur at the coast (Fig. 3A), whereas in the other scenarios for 2050 and 2080, at least up to 4 species will occur (Fig. 3B-D). All models predict that species richness will remain highest in the midlands. However, in all future scenarios, at least 3 species will be lost (Table 3). A general loss of extent in occurrence is predicted in the highland areas, especially in

Table 2. Selected bioclimatic variables (Hijmans et al. 2005a, b) and their use in species distribution model building (M1-M8). The 4 most frequently used variables are in bold. All variables are continuous data, except for catchment area (Midgley et al. 1994), which is categorical.

\begin{tabular}{|c|c|c|c|c|c|c|c|c|}
\hline Variable description & M1 & M2 & M3 & M4 & M5 & M6 & M7 & M8 \\
\hline \multicolumn{9}{|l|}{ Temperature } \\
\hline $\begin{array}{l}\text { Minimum tem- } \\
\text { perature of } \\
\text { coldest month }\end{array}$ & & & Yes & Yes & & Yes & Yes & \\
\hline $\begin{array}{l}\text { Mean temperature } \\
\text { of driest quarter }\end{array}$ & & & Yes & & & Yes & Yes & Yes \\
\hline $\begin{array}{l}\text { Mean temperature } \\
\text { of coldest quarter }\end{array}$ & & & & & & Yes & Yes & Yes \\
\hline \multicolumn{9}{|l|}{ Precipitation } \\
\hline Annual precipitation & & & & Yes & & & & \\
\hline $\begin{array}{l}\text { Precipitation of } \\
\text { wettest month }\end{array}$ & & & & & Yes & & & \\
\hline $\begin{array}{l}\text { Precipitation of } \\
\text { driest month }\end{array}$ & & & & & & & Yes & \\
\hline $\begin{array}{l}\text { Precipitation } \\
\text { seasonality } \\
\text { (coefficient } \\
\text { of variation) }\end{array}$ & & Yes & & & & & & \\
\hline $\begin{array}{l}\text { Precipitation of } \\
\text { wettest quarter }\end{array}$ & Yes & Yes & & & & & & Yes \\
\hline $\begin{array}{l}\text { Precipitation of } \\
\text { driest quarter }\end{array}$ & & Yes & & & & & & Yes \\
\hline $\begin{array}{l}\text { Precipitation of } \\
\text { warmest quarter }\end{array}$ & & Yes & Yes & Yes & & & & Yes \\
\hline $\begin{array}{l}\text { Precipitation of } \\
\text { coldest quarter }\end{array}$ & & Yes & & & & & & \\
\hline \multicolumn{9}{|l|}{ Landscape } \\
\hline Catchment area & Yes & Yes & Yes & Yes & Yes & Yes & Yes & Yes \\
\hline
\end{tabular}

the 2050 models. In contrast, in both emissions scenarios for 2080, numbers of species are as high as in the current prediction.

\section{Geographic range and elevation}

Overall, species will undergo a reduction in extent of occurrence. The decrease will range from 28 to $35 \%$ in 2050 and 32 to $45 \%$ in 2080. Three species, Brachythemis leucosticta, Hemistigma albipunctum, and Palpopleura portia, all widespread African species, will be extirpated from the study area by the year 2050 (Table 3). These species also have the narrowest elevation ranges of all species (468-1258 m; Table 4). In contrast, Pseudagrion spernatum is predicted to extend its range to $133 \%$ beyond its former extent under the A2 scenario, and by 2080 will have expanded to $143 \%$ beyond its former geographic range. Pseudagrion spernatum's elevation range will increase up to $696 \mathrm{~m}$, with $461 \mathrm{~m}$ of that change toward the upper elevations (Table 4).

Under the moderate emissions scenario (B2), species geographic ranges will increase, but with only a 160 - to $260-\mathrm{m}$ elevation change. The only unaffected species is Lestes virgatus, for which both geographic range and elevations remain the same under all scenarios. The widespread endemic Africallagma glaucum has an elevation range of $2326 \mathrm{~m}$ that is $2^{\text {nd }}$ only to the elevation range for Trithemis dorsalis. Under the A2 scenario, A. glaucum's elevation range will change little, but under the B2 scenario, the species will undergo an upward trend in elevation range from current conditions of $662 \mathrm{~m}$ in 2050 and $879 \mathrm{~m}$ in 2080 . Under the B2 scenario, A. glaucum is predicted to lose $39 \%$ of its former geographic extent. The endemic Chlorolestes fasciatus faces range reductions under all scenarios. However, under the A2 scenario, the species will initially decline $29 \%$ in 2050 and then recover to $87 \%$ of its former extent in 2080 . Under the B2 scenario, a decline of $54 \%$ in 2050 is followed by a further decline to $19 \%$ in 2080 . In contrast, the geographic range of the endemic $C$. tessellatus will remain relatively stable at $\sim 216 \mathrm{~km}^{2}$ and will range from 89 to $103 \%$. The lower range margin for C. tessellatus will move upward by $333 \mathrm{~m}$ by 2080 . In contrast, the already high lower range margin of C. fasciatus will move to only $161 \mathrm{~m}$ lower, whereas the upper range margin will move up to $880 \mathrm{~m}$ higher by 2050 under the B2 scenario. Chlorolestes fasciatus faces the greatest geographic range loss under the B2 scenario where the elevation range is similar to present conditions (Table 3).

\section{Change in habitat suitability}

Under the A2 scenario, the 2050 and 2080 predictions have in common a decrease in habitat suitability for species at the coast and the highlands, whereas in the midlands, habitat suitability both decreases and increases (Fig. 4). The 


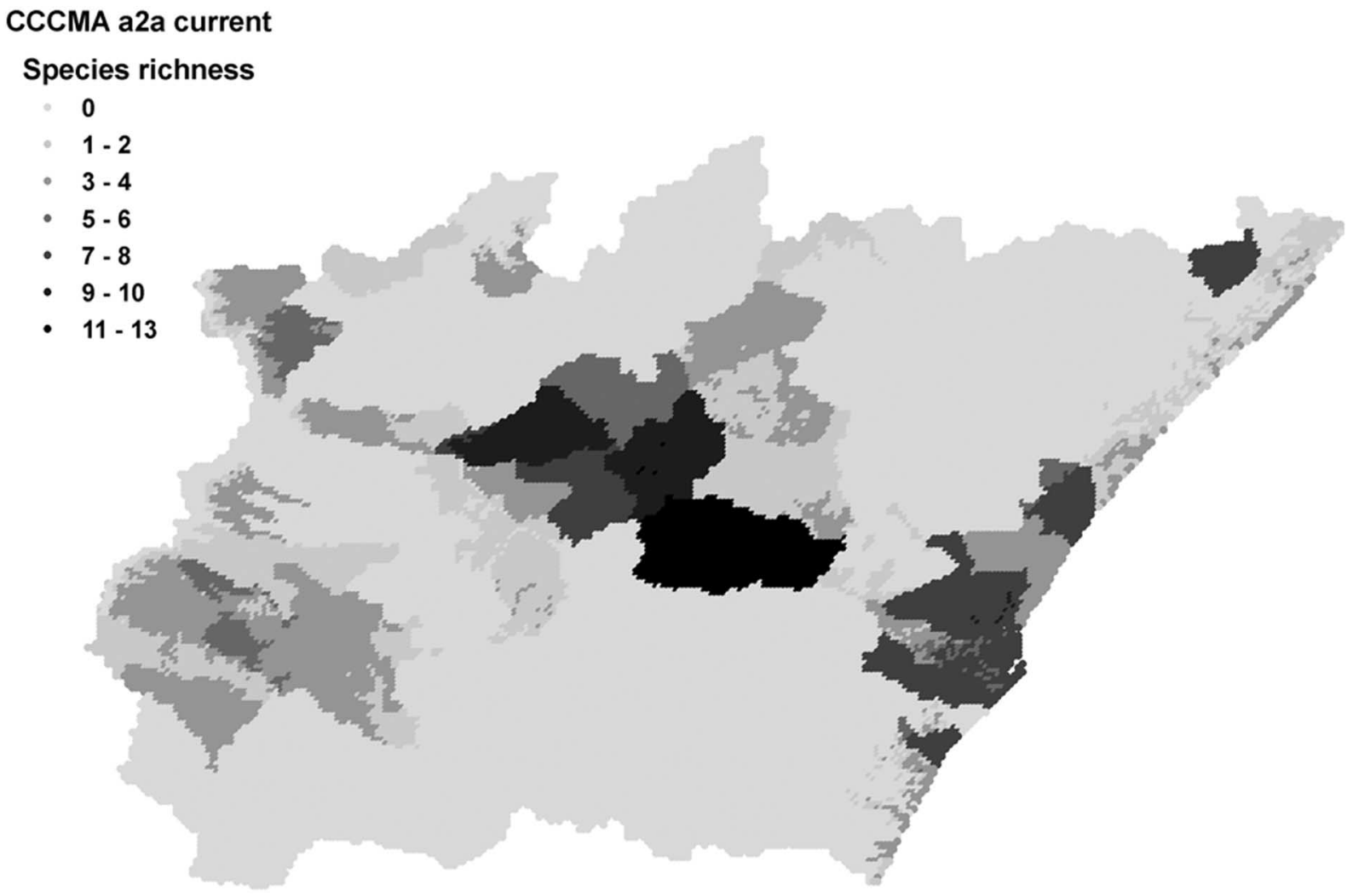

Figure 2. Predicted current distributions of dragonfly species in the study area.

B2 scenario changes the least from the current prediction, whereas the A2 scenario shows greater change, in particular in the highlands.

\section{DISCUSSION}

Coope (1995) identified 3 ways in which a species may respond to persistent climate change: 1) the species can become extinct, 2) the species can adapt in situ, or 3) the species can migrate to an area with a more tolerable climate. Evidence does exist that some insect species have become extinct because of recent climate change, and that for the future at least, accelerated rates of extinction are likely (Thomas et al. 2004). In contrast, evolution plays a minor role in faunal responses to climate change, with insect species in the past tending to have shifted their geographical ranges according to changing climatic conditions (Coope 1978, Ponel et al. 2003). This tendency does not exclude the possibility of rapid evolutionary change under future scenarios, especially when there are strong and even synergistic drivers of change (Williams 2002, Murcia et al. 2014). Unlike the first 2 responses listed above, distributional changes are recorded and studied frequently (Hassall et al. 2007).

In their study on the responsiveness of 179 animal species from various taxa (mammals, birds, reptiles, butterflies, various other invertebrate species) to climate change brought about by a doubling of $\mathrm{CO}_{2}$ in South Africa, Erasmus et al. (2002) found that $17 \%$ of species expanded their ranges, $78 \%$ displayed range contractions varying from 4 to $98 \%, 3 \%$ showed no response, and $2 \%$ became locally extinct. More importantly, most range shifts (41\%) were in an easterly direction, and highest losses of species occurred in the west. Along the Durban-Sani Pass gradient (the one we used), Erasmus et al. (2002) showed that butterflies, while slightly fewer in numbers, were overall more widely distributed in the area, as were what they classed in their analysis as 'other invertebrate taxa' (Scarabainae beetles, antlions [Neuoptera], buprestid beetles, and termites).

In our study, all modeled species are widespread, and many are common where they occur. Only 2 species, $C$. fasciatus and C. tessellatus are national endemics (Samways 2006), and their future in South Africa appears to be assured. This stability may be because the endemic species have been through many climatic bottlenecks in the past without being obliterated by glaciations, which have not occurred in the area for $>200$ my. Nevertheless, climate change is predicted to affect most species negatively. The models for 2050 and 2080 consistently predict reductions in overall species ranges, with a minimum of 28 and a maximum of $35 \%$ in 2050 and 32 and 45\%, respectively, in 2080.

Species ranges decrease less under the A2 scenario for 2050 and 2080 than under the B2 scenario for the same time periods. This prediction would seem counter-intuitive 


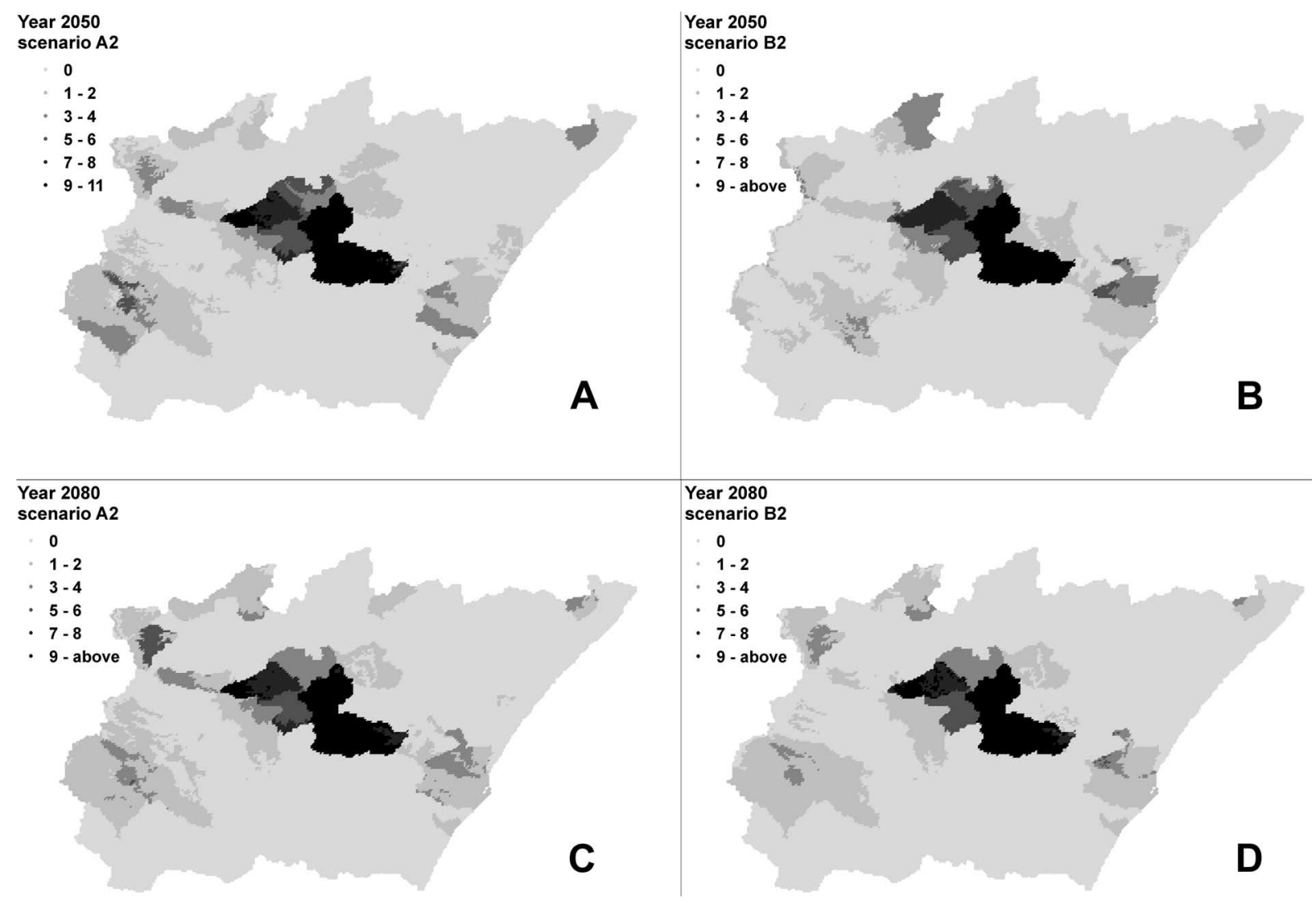

Figure 3. Predicted species richness patterns for 2050 (A, B) and 2080 (C, D) under the A2 (A, C) and B2 (B, D) climate scenarios.

because the A2 scenario is considered more severe than the $\mathrm{B} 2$ scenario. This prediction does make ecological sense because most of the species considered here are widespread and tolerant of water-scarce environments and, therefore, should be able to breed in temporary habitats including small ponds and pools and artificial reservoirs. In other words, these less-sensitive species stand to benefit from the deterioration of permanent lotic habitat, such as the

Table 3. Geographic ranges of modeled species, expressed here as number of grid cells, under current and future (2050, 2080) predicted global climate-change scenarios. Predicted changes are expressed as percentages.

\begin{tabular}{|c|c|c|c|c|c|c|c|c|c|}
\hline \multirow[b]{2}{*}{ Species } & \multirow[b]{2}{*}{ Now } & \multicolumn{4}{|c|}{ Scenario A2 } & \multicolumn{4}{|c|}{ Scenario B2 } \\
\hline & & 2015 & Now-2050 & 2080 & Now-2080 & 2015 & Now-2050 & 2080 & Now-2080 \\
\hline Africallagma glaucum & 5200 & 4751 & 91 & 4329 & 83 & 5088 & 98 & 3194 & 61 \\
\hline Brachythemis leucosticta & 1151 & 0 & 0 & 0 & 0 & 0 & 0 & 0 & 0 \\
\hline Chlorolestes fasciatus & 4636 & 3283 & 71 & 4011 & 87 & 2117 & 46 & 880 & 19 \\
\hline Chlorolestes tessellatus & 2640 & 2362 & 89 & 2352 & 89 & 2719 & 103 & 2352 & 89 \\
\hline Hemistigma albipunctum & 1887 & 2 & 0 & 0 & 0 & 0 & 0 & 0 & 0 \\
\hline Lestes virgatus & 2257 & 2257 & 100 & 2257 & 100 & 2257 & 100 & 2257 & 100 \\
\hline Nesciothemis farinosa & 3543 & 2809 & 79 & 3135 & 88 & 1429 & 40 & 2890 & 82 \\
\hline Palpopleura portia & 2497 & 0 & 0 & 0 & 0 & 0 & 0 & 0 & 0 \\
\hline Pseudagrion kersteni & 3933 & 1855 & 47 & 1853 & 47 & 2956 & 75 & 2344 & 60 \\
\hline Pseudagrion massaicum & 2123 & 1817 & 86 & 1077 & 51 & 1077 & 51 & 1077 & 51 \\
\hline Pseudagrion spernatum & 3868 & 5145 & 133 & 5601 & 145 & 4461 & 115 & 5583 & 143 \\
\hline Trithemis arteriosa & 5438 & 2990 & 55 & 2769 & 51 & 4036 & 7 & 2054 & 38 \\
\hline Trithemis dorsalis & 4967 & 4978 & 100 & 4200 & 85 & 4151 & 84 & 5226 & 105 \\
\hline Trithemis furva & 2945 & 2659 & 90 & 2780 & 94 & 2469 & 84 & 2916 & 99 \\
\hline Total species range & 47085 & 34908 & 74 & 34364 & 73 & 32760 & 70 & 27812 & 59 \\
\hline
\end{tabular}



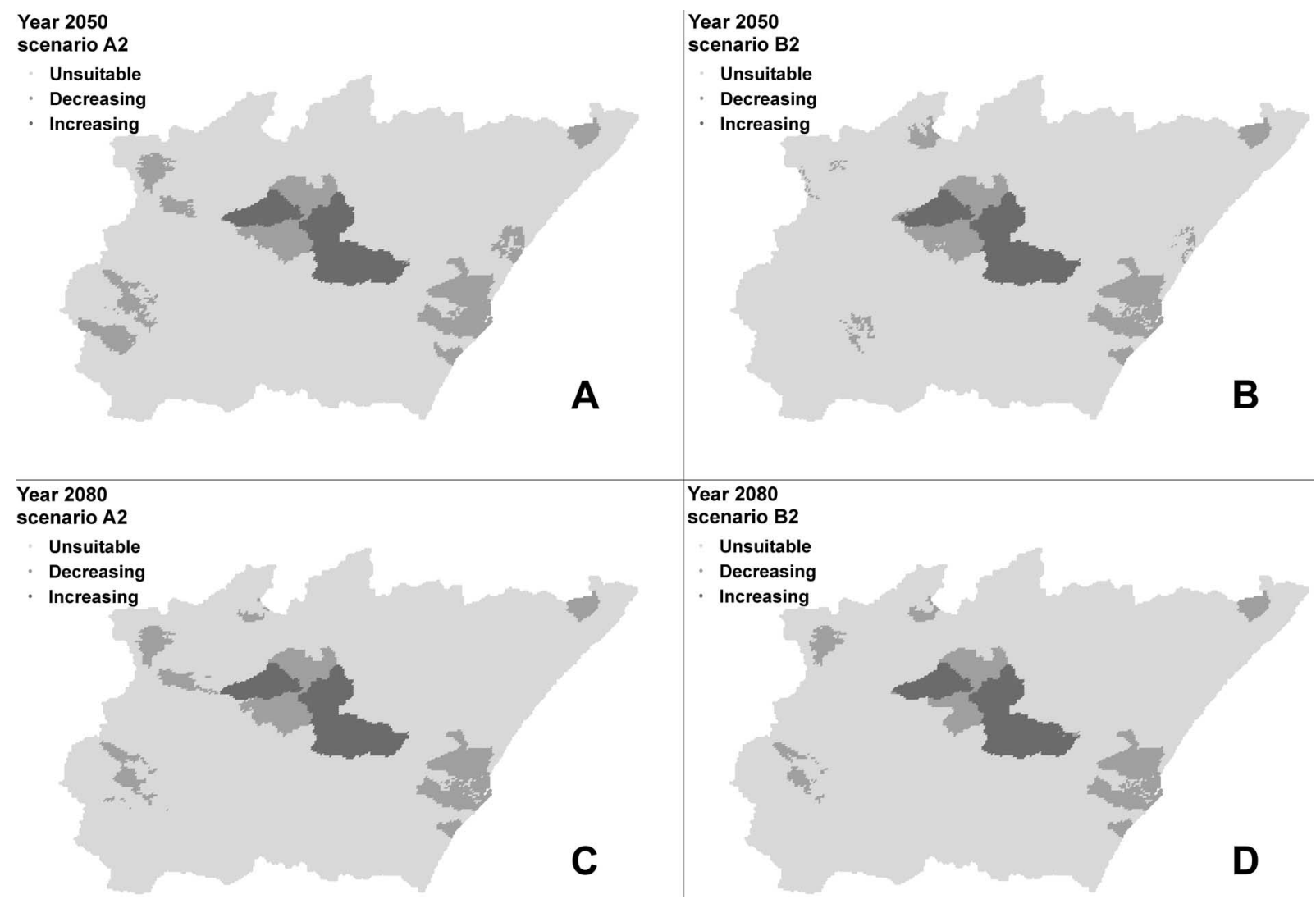

Figure 4. Predicted range of habitat change for 2050 (A, B) and 2080 (C, D) under the A2 (A, C) and B2 (B, D) climate scenarios from the current prediction.

change of perennial streams to ephemeral habitats. In addition, as water shortages increase, so too will the number of reservoirs used for irrigation, further giving habitat opportunities to tolerant species.

Three species, Brachythemis leucosticta, Hemistigma albipunctum, and Palpopleura portia, face local extinction from the study area in the long term. All these species are widespread, but have relatively narrow elevation ranges compared to other species in the study. The ranges of these 3 species extend marginally into our study area, and therefore, a loss of these species probably would indicate that they are shifting out of the study area, most likely westward. Pseudagrion spernatum is a stream specialist, but its geographic spread and remarkable elevation tolerance will give it an advantage in the changing climatic conditions. The only highelevation specialist, C. fasciatus, is predicted to extend to lower and to higher elevations, with most of the change to higher elevations.

Species at high elevations tend to be thermally tolerant because of the breadth of climatic conditions encountered at higher elevations. Indeed, this tolerance is supported by the climatic variability hypothesis (Stevens 1992, Gaston and Chown 1999) that an increase in the elevation range of occurrence of a species in an assemblage with increasing elevation can be explained as a consequence of individuals having to withstand a broader range of climatic conditions. Gaston and Chown (1999) tested this hypothesis on an assemblage of 26 scarab dung beetle species along an elevation transect of $2500 \mathrm{~m}$ by using thermal tolerance as a measure of climatic tolerance. They found evidence for a general increase in temperature-tolerance range of the dung beetles across the elevation gradient, a result that supports the climate variability hypothesis. Therefore, ecological support may exist for the model results, in that because C. fasciatus occurs at higher elevations, the species' altitudinal range also would increase.

Under the A2 scenario, C. fasciatus will initially face a reduced geographic range, followed by a recovery of some of that range. In contrast, under the B2 scenario, the species faces a continued decline of up to $81 \%$ of its former range. The general range reduction of this habitat specialist, despite the increasing elevation range to higher elevations, will occur because less-suitable habitat is available at higher than at lower elevations. This conclusion is supported by preliminary evidence that this species has, to some extent, a glacial-relict distribution. For example, it occurs in the low, but watered mountain peaks of the Mountain Zebra National Park, is absent from the extensive and totally surrounding lower and drier areas (Samways 2006), and occurs in some locations, such as at Umtamvuna, at sea 
Table 4. Current and future predicted elevation tolerances of species under 2 climate scenarios, A2 and B2, for 2050 and 2080. Minimum ( $\min )$, maximum $(\max )$, and range of elevations are given in meters. Range = difference between the minimum and maximum recorded elevation, $\mathrm{na}=$ not applicable. Habitat codes: * = endemic, $\mathrm{g}=$ habitat generalist, $\mathrm{s}=$ habitat $\mathrm{specialist}$, $\mathrm{l}=$ lentic, $\mathrm{o}=$ lotic, $\mathrm{c}=$ localized, $\mathrm{w}=$ widespread, $\mathrm{f}=$ forest habitat $-=$ narrow elevation range,$+=$ wide elevation range .

\begin{tabular}{|c|c|c|c|c|c|c|c|c|c|c|c|c|c|c|c|c|}
\hline \multirow[b]{2}{*}{ Species } & \multirow[b]{2}{*}{ Code } & \multicolumn{3}{|c|}{ Present } & \multicolumn{3}{|c|}{ A2 2050} & \multicolumn{3}{|c|}{ A2 2080} & \multicolumn{3}{|c|}{ B2 2050} & \multicolumn{3}{|c|}{ B2 2080} \\
\hline & & Iin & Max & ange & Min & Max & Range & Min & Max & $\mathrm{Ra}$ & Min & Max & & Min & Max & Range \\
\hline fricallagma glaucum & glw & 13 & 2339 & 326 & 27 & 2369 & 2342 & 26 & 2318 & 2292 & 14 & 3002 & 2900 & 27 & 3232 & 3205 \\
\hline Brachythemis leucosticta & glw- & 20 & 990 & 970 & na & na & na & na & na & na & na & na & na & na & na & na \\
\hline Chlorolestes fasciatus & *o & 045 & 2368 & 1323 & 999 & 3142 & 2143 & 1004 & 3132 & 2128 & 884 & 3248 & 2364 & 1074 & 2677 & 1603 \\
\hline Chlorolestes tessellatus & *of & 15 & 1768 & 1753 & 92 & 1768 & 1676 & 348 & 1768 & 1420 & 15 & 1768 & 1753 & 348 & 1768 & 1420 \\
\hline Hemistigma albipunctum & g- & 2 & 470 & 168 & 13 & 11 & 31 & na & n? & no & na & no & 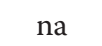 & na & n? & no \\
\hline Lestes virgatus & glcf & 4 & 1293 & 10 & 4 & 1293 & & 4 & 1293 & 9 & 4 & 1293 & 1 & 4 & 1293 & 1289 \\
\hline sciothemis farinosa & glw & 4 & 1768 & 1764 & 12 & 1768 & 1756 & 10 & 1768 & 1758 & 348 & 1293 & 945 & 12 & 1768 & 1756 \\
\hline Palpopleura portia & glw- & 4 & 1262 & 1258 & na & na & na & na & na & na & na & na & na & na & na & na \\
\hline Pseudagrion kersteni & $\mathrm{s}+$ & 4 & 1840 & 1836 & 441 & 2176 & 1735 & 345 & 2176 & 1831 & 12 & 2431 & 2419 & 528 & 2128 & 1600 \\
\hline Pseudagrion massaicum & glw & 12 & 1578 & 1566 & 4 & 1340 & 1336 & 39 & 1262 & 1223 & 39 & 1262 & 1223 & 39 & 1262 & 1223 \\
\hline Pseudagrion spernatum & so & 583 & 2593 & 2010 & 348 & 3054 & 2706 & 348 & 3054 & 2706 & 348 & 2509 & 2161 & 385 & 2651 & 2266 \\
\hline Trithemis arteriosa & glw & 4 & 1835 & 1831 & 22 & 2437 & 2415 & 105 & 2657 & 2552 & 12 & 3004 & 2992 & 361 & 1895 & 1534 \\
\hline Trithemis dorsalis & glw & 250 & 3246 & 2996 & 242 & 3127 & 2885 & 547 & 2337 & 1790 & 371 & 3254 & 2883 & 250 & 3246 & 2996 \\
\hline Trithemis furva & sow & 12 & 1593 & 1581 & 10 & 1799 & 1789 & 68 & 1773 & 1705 & 15 & 1509 & 1494 & 12 & 1735 & 1723 \\
\hline
\end{tabular}

level (Samways and Simaika 2015). This distribution pattern suggests that $C$. fasciatus has remarkable elevation tolerance that might have been honed by deep history and by more recent ENSO events.

The model predictions in our study clearly indicate that most species will experience reduced extent of occurrence and will become more localized, while at the same time, species composition will change. Furthermore, the reduction in the number of species and, therefore, competition for habitat, could cause some species to become more common. These changes probably will cause a change in local community structure, but it is difficult to foresee that restructuring of the species assemblages would affect trophic interactions (e.g., Winder and Schindler 2004), mainly because dragonflies have nonspecialist diets (but see Knight et al. 2005 on trophic effects across ecosystems). A further consideration is that several species that occur farther north in southern Africa, some of which have ranges that currently extend south to just inside South Africa, may move farther southward in the country. This situation is highly likely because several species temporally extend and contract their ranges mostly north-south according to ENSO events and regularly become present and then locally extinct (Samways 2010). In addition, several species move up and down in elevation on a temporary basis depending on prevailing climate (Samways and Niba 2010).

Most species in our study thrive in artificial environments, such as reservoirs, but also in roadside ditches and other artificial water features. Therefore, to a certain extent, loss in connectivity or changes in hydrological con- ditions are unlikely to affect these species. However, stream specialists, such as the nationally endemic species C. fasciatus and C. tessellatus, are far more vulnerable. These species are adapted to cool, oligotrophic, acidic stream conditions (Samways and Simaika 2015). Coastal habitats are predicted to become warmer, resulting in increased evaporation (Schulze et al. 2011). Intensified coastal winds are likely to increase this effect. Increases in rainfall volume and intensity, and consequently increased sedimentation, are likely to result in negative changes to stream geomorphology and, thus, to affect the ability of larvae to cope in their aquatic habitats. In addition, stream species (C. fasciatus at higher elevations and C. tessellatus at lower ones) are vulnerable to the effects of forestry and invasive alien woody plants. This threat is real because increasing $\mathrm{CO}_{2}$ concentrations in the atmosphere are predicted to dramatically contribute to woody plant growth (Wigley et al. 2010). Both species benefit from clearing of invasive alien tree and creation of large-scale natural corridors (ecological networks) along streams in their natural habitat. These corridors will be increasingly important in the future as a means of maintaining connectivity across the landscape and for allowing these species and others to track climate change without the inhibition of a fragmented landscape (Samways 2010).

\section{ACKNOWLEDGEMENTS}

This manuscript was completed with support from a Claude Leon Postdoctoral Fellowship and funding from Stellenbosch 
University's Subcommittee B. Computations were performed using the University of Stellenbosch's Rhasatsha High Performance Computer (http://www.sun.ac.za/hpc).

\section{LITERATURE CITED}

Bellard, C., C. Bertelsmeier, P. Leadley, W. Thuiller, and F. Courchamp. 2012. Impacts of climate change on the future of biodiversity. Ecology Letters 15:365-377.

Bourg, N. A., W. J. McShea, and D. E. Gill. 2005. Putting a CART before the search: successful habitat prediction for a rare forest herb. Ecology 86:2793-2804.

Brooke, C. 2008. Conservation and adaptation to climate change. Conservation Biology 22:1471-1476.

Bush, A., G. Theischinger, D. Nipperess, E. Turak, and L. Hughes. 2013. Dragonflies: climate canaries for river management. Diversity and Distributions 19:86-97.

Coope, G. R. 1978. Constancy of insect species versus inconstancy of Quaternary environments. Pages 176-187 in L. A. Mound and N. Waloff (editors). Diversity of insect faunas. Blackwell Scientific Publications, Oxford, UK.

Coope, G. R. 1995. Insect faunas in ice age environments: why so little extinction? Pages 55-74 in J. H. Lawton and R. M. May. Extinction rates. Oxford University Press, New York.

Darwall, W. R. T., R. A. Holland, K. G. Smith, D. Allen, E. G. E. Brooks, V. Katarya, C. M. Pollock, Y. Shi, V. Clausnitzer, N. Cumberlidge, A. Cuttelod, K.-D. B. Dijkstra, M. D. Diop, N. Garcia, M. B. Seddon, P. H. Skelton, J. Snoeks, D. Tweddle, and J.-C. Vie. 2011. Implications of bias in conservation research and investment for freshwater species. Conservation Letters 4:474-482.

Dawson, T. P., P. M. Berry, and E. Kampa. 2003. Climate change impacts on freshwater wetland habitats. Journal for Nature Conservation 11:25-30.

De Marco, P., C. Corrêa Nóbrega, R. Souza, U. G. Neiss, and B. Constant. 2015. Modeling the distribution of a rare Amazonian odonate in relation to future deforestation. Freshwater Science 34:1123-1132.

Driver, A., K. Maze, M. Rouget, A. T. Lombard, J. L. Nel, J. K. Turpie, R. M. Cowling, P. Desmet, P. Goodman, J. Harris, Z. Jonas, B. Reyers, K. Sink, and T. Strauss. 2005. National spatial biodiversity assessment 2004: priorities for biodiversity conservation in South Africa. Strelitzia 17:1-45.

Dudgeon, D., A. H. Arthington, M. Gessner, Z.-I. Kawabata, D. J. Knowler, C. Lévêque, R. J. Naiman, A.-H. PrieurRichard, M. L. J. Stiassny, and C. A. Sullivan. 2006. Freshwater biodiversity: importance, threats, status and conservation challenges. Biological Reviews 81:163-182.

Elith, J., C. H. Graham, R. P. Anderson, M. Dudík, S. Ferrier, A. Guisan, R. J. Hijmans, F. Huettmann, J. R. Leathwick, A. Lehmann, J. Li, L. G. Lohmann, B. A. Loiselle, G. Moritz, M. Nakamura, Y. Nakazawa, J. M. Overton, A. T. Peterson, S. J. Phillips, K. Richardson, R. Scachetti-Pereira, R. E. Schapire, J. Soberón, S. Williams, M. S. Wisz, and N. E. Zimmermann. 2006. Novel methods improve prediction of species' distributions from occurrence data. Ecography 29:129-151.

Elith, J., and J. Leathwick. 2009. Conservation prioritisation using species distribution modelling. Pages 70-93 in A. Moilanen, K. A. Wilson, and H. Possingham (editors). Spatial conserva- tion prioritization: quantitative methods and computational tools. Oxford University Press, Oxford, UK.

Erasmus, B. N., A. Van Jaarsveld, S. L. Chown, M. Kshatriya, and K. J. Wessels. 2002. Vulnerability of South African animal taxa to climate change. Global Change Biology 8:679-693.

Ficetola, G. F., W. Thuiller, and C. Miaud. 2007. Prediction and validation of the potential global distribution of a problematic alien invasive species-the American bullfrog. Diversity and Distributions 13:476-485.

Franklin, F. 2010. Moving beyond static species distribution models in support of conservation biogeography. Diversity and Distributions 16:321-330.

Gaston, K. J., and S. L. Chown. 1999. Elevation and climatic tolerance: a test using dung beetles. Oikos 86:584-590.

Grant, P. B. C., and M. J. Samways. 2007. Montane refugia for endemic red-listed dragonflies of the Cape Floristic Region biodiversity hotspot. Biodiversity and Conservation 16:787-805.

Hassall, C., and D. J. Thompson. 2008. The impacts of environmental warming on Odonata: a review. International Journal of Odonatology 11:131-153.

Hassall, C., D. J. Thompson, G. C. French, and I. F. Harvey. 2007. Historical changes in the phenology of British Odonata are related to climate change. Global Climate Change 13:1-9.

Hijmans R. J., S. E. Cameron, J. L. Parra, P. G. Jones, and A. Jarvis. 2005a. Very high resolution interpolated climate surfaces for global land areas. International Journal of Climatology 25: 1965-1978.

Hijmans, R. J., L. Guarino, A. Jarvis, R. O'Brien, P. Mathur, C. Bussink, M. Cruz, I. Barrantes, and E. Rojas. 2005b. DIVA-GIS version 5.2 manual. University of California, Davis, California. (Available from: www.diva-gis.org)

IPCC (Intergovernmental Panel on Climate Change). 2007. Summary for policymakers. Pages 1-18 in S. Solomon, D. Qin, M. Manning, Z. Chen, M. Marquis, K. B. Averyt, M. Tignor, and H. L. Miller (editors). Climate Change 2007: the physical science basis. Contribution of Working Group I to the $4^{\text {th }}$ Assessment Report of the Intergovernmental Panel on Climate Change. Cambridge University Press, Cambridge, UK.

Knight, T. M., M. W. McCoy, J. M. Chase, K. A. McCoy, and R. D. Holt. 2005. Trophic cascades across ecosystems. Nature 473:880-883.

MA (Millennium Ecosystem Assessment). 2005. Ecosystems and human well-being: biodiversity synthesis. World Resources Institute, Washington, DC.

Middleton, B. A., and T. Kleinebecker. 2012. The effects of climate-change-induced drought and freshwater wetlands. Global Change and the Function and Distribution of Wetlands 1:117-147.

Midgley, D. C., W. V. Pitman, and B. J. Middleton. 1994. Surface water resources of South Africa 1990: user's manual. Report No. 298/1/94. Water Resource Commission, Pretoria, South Africa.

Murcia, C., J. Aronson, G. H. Kattan, D. Moreno-Mateos, K. Dixon, and D. Simberloff. 2014. A critique of the 'novel ecosystem' concept. Trends in Ecology and Evolution 29:548-553.

Nel, J. L., D. J. Roux, G. Maree, C. J. Kleynhans, J. Moolman, B. Reyers, M. Rouget, and R. M. Cowling. 2007. A systematic conservation assessment of the ecosystem status and protection levels of main rivers in South Africa. Diversity and Distributions 13:341-352. 
Newbold, T. 2010. Applications and limitations of museum data for conservation and ecology, with particular attention to species distribution models. Progress in Physical Geography 34:3-22.

Ott, J. (editor). 2011. Dragonflies and climate change. Pensoft, Sophia, Bulgaria.

Pearce, J., and S. Ferrier. 2000. Evaluating the predictive performance of habitat models developed using logistic regression. Ecological Modelling 133:225-245.

Phillips, S. J., R. P. Anderson, and R. E. Schapire. 2006. Maximum entropy modeling of species geographic distributions. Ecological Modelling 190:231-259.

Phillips, S. J., and M. Dudik. 2008. Modeling of species distributions with Maxent: new extensions and a comprehensive evaluation. Ecography 31:161-175.

Ponel, P., J. Orgeas, M. J. Samways, V. Andrieu-Ponel, J. L. De Beaulieu, M. Reille, P. Roche, and T. Tatoni. 2003. 110000 years of Quaternary beetle diversity change. Biodiversity and Conservation 12:2077-2089.

Samways, M. J. 1989. Farm dams as nature reserves for dragonflies (Odonata) at various altitudes in the Natal Drakensberg Mountains, South Africa. Biological Conservation 48:181-187.

Samways, M. J. 2006. National Red List of South African Odonata. Odonatologica 35:341-368.

Samways, M. J. 2010. Extreme weather and climate change impacts on South African dragonflies. Pages 73-84 in J. Ott (editor). Monitoring climate change with dragonflies. Pensoft, Sophia, Bulgaria.

Samways, M. J., and A. S. Niba. 2010. Climate and elevational range of a South African dragonfly assemblage. Pages 85-107 in J. Ott (editor). Monitoring climate change with dragonflies. Pensoft, Sophia, Bulgaria.

Samways, M. J., N. J. Sharratt, and J. P. Simaika. 2011. Effect of alien riparian vegetation and its removal on a highly endemic river macroinvertebrate community. Biological Invasions 13: $1305-1324$.

Samways, M. J., and J. P. Simaika. 2015. Handbook of freshwater assessment: the South African biotic index. South African National Biodiversity Institute, Pretoria, South Africa.

Schindler, M., C. Fesl, and A. Chovanec. 2003. Dragonfly associations (Insecta: Odonata) in relation to habitat variables: a multivariate approach. Hydrobiologia 497:169-180.

Schulze, R. E., B. C. Hewitson, K. R. Barichievy, M. A. Tadross, R. P. Kunz, M. J. C. Horan, and T. G. Lumsden. 2011. Methodological approaches to assessing eco-hydrological response to climate change in South Africa. Report No. 1562/1/10. Water Research Commission, Pretoria, South Africa.
Shah, R. D. T., D. N. Shah, and S. Domisch. 2012. Range shifts of a relict Himalayan dragonfly in the Hindu Kush Himalayan region under climate change scenarios. International Journal of Odonatology 15:209-222.

Simaika, J. P., and M. J. Samways. 2009a. An easy-to-use index of ecological integrity for prioritizing freshwater sites and for assessing habitat quality. Biodiversity and Conservation 18: 1171-1185.

Simaika, J. P., and M. J. Samways. 2009b. Reserve selection using red-listed taxa in three global biodiversity hotspots: dragonflies in South Africa. Biological Conservation 142:638-651.

Simaika, J. P., M. J. Samways, J. Kipping, F. Suhling, K.-D. B. Dijkstra, V. Clausnitzer, J. P. Boudot, and S. Domisch. 2013. Continental-scale conservation prioritization of dragonflies. Biological Conservation 157:245-254.

Stevens, G. C. 1992. The elevational gradient in altitudinal range: an extension of Rapoport's latitudinal rule to altitude. American Naturalist 140:893-911.

Stuart, Y. E., T. S. Campbell, P. A. Hohenlohe, R. G. Reynolds, I. J. Revell, and J. B. Losos. 2014. Rapid evolution of a native species following invasion by a congener. Science 346:463-465.

Thomas, C. D., A. Cameron, R. E. Green, M. Bakkenes, L. J. Beaumont, Y. C. Collingham, B. F. N. Erasmus, M. Ferreira de Siqueira, A. Grainger, L. Hannah, L. Hughes, B. Huntley, A. S. van Jaarsveld, G. F. Midgley, L. Miles, M. A. Ortega-Huerta, A. T. Peterson, O. L. Phillips, and S. E. Williams. 2004. Extinction risk from climate change. Nature 427:145-148.

Trevino, J. 1997. Dragonfly naiads as an indicator of water quality. Technical Note No. 99. Watershed Protection Techniques 2:533-535.

Wellenreuther, M., K. W. Larson, and E. I. Svensson. 2012. Climatic niche divergence or conservatism? Environmental niches and range limits in ecologically similar damselflies. Ecology 93:1353-1366.

Wigley, B. J., W. J. Bond, and M. T. Hoffman. 2010. Thicket expansion in a South African savanna under divergent land use: local vs. global drivers? Global Change Biology 16:964-976.

Williams, B. L. 2002. Conservation genetics, extinction, and taxonomic status: a case history of the regal fritillary. Conservation Biology 16:148-157.

Winder, M., and D. E. Schindler. 2004. Climate change uncouples trophic interactions in an aquatic ecosystem. Ecology 85:21002106.

Wishart, M. J., and J. A. Day. 2002. Endemism in the freshwater fauna of the south-western Cape, South Africa. Verhandlungen der Internationalen Vereinigung für theoretische und angewandte Limnologie 28:1-5. 